\title{
Pengaruh Penggunaan Media Sosial Terhadap Ekuitas Merek Agen Perjalanan Daring
}

\author{
Adriantono Candram Haranna Farghani, Romy Haidar. Vito Farisan \\ School of Business and Economics Universitas Prasetiya Mulya \\ JL. RA. Kartini (TB Simatupang), Cilandak Barat Jakarta Selatan, Jakarta 12430 Indonesia
}

Corresponding Author:01511181012@student.prasetiyamulya.ac.id

\begin{abstract}
Abstrak
Penulisan ini dibuat untuk melihat respon konsumen terhadap ekuitas merek agen perjalanan daring serta pengaruh ekuitas merek secara keseluruhan kepada konsumen melalui media sosial. Kuesioner diberikan kepada setiap pengguna sebagai responden. Dari 340 responden, 329 responden diantaranya menyatakan bahwa pernah melihat agen perjalanan daring di media sosial. Hipotesa yang ada diuji menggunakan analisis regresi. Penulisan menunjukkan bahwa setiap variabel yang ada berpengaruh terhadap ekuitas merek. Dampak positif yang muncul ditunjukkan melalui hasil setiap variabel. Kesadaran merek sebagai variabel yang berpengaruh besar, dapat mendorong ekuitas merek secara komprehensif. Penulisan ini memperlihatkan bahwa ekuitas merek berperan penting. Merek merupakan identitas yang melambangkan sebuah produk. Kemudian, merek juga berfungsi sebagai pengendali pasar.
\end{abstract}

Kata kunci - Ekuitas Merek, Asosiasi Merek, Loyalitas Merek, Citra Merek, Kesadaran Merek, Media Sosial

\begin{abstract}
This writing was made to see consumer responses to brand equity from online travel agents and the overall effect of brand equity on consumers through social media. The questionnaire was given to each user as a respondent. Out of 340 respondents, 329 of them stated that they had seen an online travel agent on social media. Existing hypotheses were tested using regression analysis. The writing shows that every variable that exists affects brand equity. The positive impact that appears is shown through the results of each variable. Brand awareness as a large influential variable, can drive brand equity comprehensively. This paper shows that brand equity plays an important role. A brand is an identity that symbolizes a product. Then, the brand also functions as a market controller.
\end{abstract}

Keywords - Brand Equity, Brand Association, Brand Loyalty, Brand Image, Brand Awareness, Social Media 


\section{Pendahuluan}

Usaha yang melayani jasa perjalanan dari saat ini khususnya di Indonesia sudah semakin menjamur, khususnya di Indonesia terdapat perusahaan startup yang mendominasi seperti Traveloka, Tiket.com, Trivago, PegiPegi, dll. karena model bisnis yang menarik dimana selain dapat memudahkan para penggunanya juga membuat suatu proses yang dulunya berbelit menjadi flexible dan bisa diakses dimanapun asalkan terdapat Internet. Karena untuk aksesnya adalah secara daring atau online maka aktivitas marketing yang dilakukan pun juga memakai saluran online marketing yang sekiranya juga dapat mudah menggaet sasaran konsumen muda yang aktivitasnya kebanyakan melalui daring.

Penggunaan media sosial menjadi sarana saluran digital merupakan hal yang lumrah atau biasa digunakan oleh banyak perusahaan sebagai alternatif lain selain saluran konvensional yaitu ATL (Above The Line) atau BTL (Below The Line) seperti halnya televisi, radio, media cetak koran, majalah, dsb, yang biasanya memakan biaya yang tidak sedikit serta untuk pengukuran tingkat penyampaian pesan yang sulit menjadi alat ukur bahwa kampanye dari hasil konten yang diciptakan sukses untuk menggaet masyarakat luas dikarenakan sifatnya yang masif dapat menjangkau khalayak banyak tetapi tidak adanya penyaring atau batasan yang membuat hasil dari pengeluaran yang dikeluarkan dapat efektif sesuai dengan target sasaran konsumen yang dituju.

Oleh karena itu marketing konsep yang akan kami gunakan disini untuk melihat pengaruh dari penggunaan media sosial yaitu brand equity yang biasa digunakan oleh para praktisi maupun akademisi, karena penggunaannya yang dapat menjadikan perusahaan dapat memiliki keunggulan bersaing. Selain itu dapat membantu para konsumen juga dalam mengambil keputusan pembelian karena sifatnya yang dapat berpengaruh terhadap sikap dan perilaku konsumen yang melihat brand equity sebagai tolak ukur nilai dari suatu brand sehingga dampak yang dihasilkan dapat berpengaruh menjadi aksi pembelian.

Melihat dari banyaknya konten yang dihasilkan oleh media sosial dan hampir setiap minggu atau setiap bulannya terjadi pembaharuan serta iklan yang masive dilakukan di media sosial yang membuatnya sering muncul di berbagai platform sosial media, membuat brand equity juga semestinya memiliki nilai yang positif juga di mata konsumen karena layanan yang diberikan akan menyesuaikan dengan objektif atau rancangan yang akan diusung sehingga 
layanan yang diberikan dapat memenuhi kebutuhan konsumen serta memuaskan konsumen yang dimana dapat berdampak terhadap peningkatan pendapatan dan profit perusahaan.

Penelitian sejenis mengenai penggunaan sosial media terhadap ekuitas merek sebenarnya sudah pernah dilakukan, oleh karena itu disini penulis akan melakukan replikasi pembahasan yang temanya adalah pandangan anak muda mengenai brand equity (Sasmita \& Suki 2015) yang dimana aktivitas yang sering dilakukan adalah menggunakan media sosial sehingga dapat berpengaruh terhadap kontribusi peningkatan penjualan perusahaan. Jika pembahasan sebelumnya pernah dilakukan di Malaysia maka penelitian kali ini dibuat untuk konteks Indonesia, dengan responden mayoritas adalah anak muda yang masih bersekolah, melanjutkan kuliah, sampai bekerja menjadi karyawan swasta maupun berwiraswasta.

Dalam pembahasan penelitian memiliki tahapan-tahapan konstruk sebagai berikut: seksi berikut adalah Tinjauan Pustaka dan Pengembangan, setelah itu hipotesis, Metodologi Penelitian, Analisis Data, dan yang terakhir yaitu kesimpulan.

\section{Tinjauan Pustaka \& Pengembangan}

\section{What is Brand Equity}

Pengertian mengenai definisi dari brand equity sebenarnya telah banyak diperdebatkan dan tidak ada satupun dari pengertian tersebut yang memiliki definisi dan kesepakatan yang sama (Vazquez et al., 2002; Keller 2003). Oleh karena itu pengertian mengenai brand equity dapat dilihat dari berbagai sudut pandang seperti manufaktur, Pengecer, atau konsumen. Seperti contoh: manufaktur dan pengecer lebih mementingkan implikasi strategi, Investor lebih mementingkan konsep definisi dari finansial (Cobb-walgren \& Ruble 1995). Dari sudut pandang finansial melihat brand equity sebagai total dari aset brand yang terpisah, seperti jika barang produk terjual atau dimasukkan ke neraca keuangan (Feldwick 1996). Terdapat juga definisi alternatif dari sudut pandang yang sama dengan menganggap brand equity sebagai arus kas tambahan yang akan bertambah terhadap produk bermerek dibandingkan dengan produk yang tidak bermerek (Simon \& Sullivan 1993).

Tetapi jika dilihat dari sudut pandang marketing melihat brand equity sebagai suatu kekuatan brand sehingga menganggapnya sebagai "customer brand equity" yang membedakannya dari pengertian penilaian aset (Wood 2002). Customer based-brand equity menggunakan pendekatan dari subjek pembeli sehingga melihatnya dari sudut pandang 
konsumen. oleh karena itu, kekuatan dari brand terdapat pada apa yang konsumen lihat, rasakan, dengan, dan pelajari mengenai merek sebagai hasil dari pengalaman penggunaan (Keller 2003). Jika brand tidak memiliki arti apapun oleh konsumen, berarti definisi tersebut tidak dapat diperhitungkan atau tidak memiliki arti bagi konsumen (Keller 2003; Cob-Walgren \& Ruble, 1995; Rio et al, 2001a). Sehingga, pengertian dari berbasis pelanggan dari ekuitas merek yang dibuat oleh Keller (2003) sebagai "perbedaan respon tentang pengetahuan brand yang dimiliki oleh konsumen terhadap pemasaran merek tersebut".

Sebenarnya terdapat definisi lain mengenai ekuitas merek yang dapat dilihat dari bermacam-macam sudut pandang yang salah satu-nya paling dapat diterima dan paling menyeluruh (Motameni \& Shahrokhi 1998) yaitu "merek yang terbagi atas aset merek dan passiva merek yang berhubungan terhadap simbol merek dan nama merek yang dapat menjadi penambah atau pengurang nilai suatu produk atau jasa ke perusahaan atau konsumen" (Aaker 1991, p. 15).

\section{Brand Equity Measurement}

Pembelajaran mengenai pengukuran brand equity dapat dibagi menjadi dua kategori. Dalam hal pendefinisian, seperti beberapa penulis mempelajari dan menggunakan brand equity dari aspek finansial-nya sebagai alat ukur dan yang dimana lainnya berfokus kepada customerbased sebagai alat ukur. Di dalam pembelajaran berbasis orientasi finansial, Simon dan Sullivan (1993) menekankan pendekatan makro dan mikro sebagai teknik estimasi dengan mengambil nilai dari ekuitas merek atas nilai suatu aset perusahaan (value of the firm) lain-lain. Jika menggunakan pendekatan makro yaitu dengan pertama kali membagi nilai objektif brand perusahaan dan menghubungkan nilai ini dengan brand equity sebagai penentu.

Sedangkan pendekatan mikro yaitu dengan memisahkan perubahan ekuitas merek dari level merek secara individu. Sama seperti pembelajaran Simon and Sullivan (1993), Motameni and Shahkroni (1998) mengajukan model valuasi global ekuitas merek dengan menghitung semua komponen dan mengaplikasikan teknik finansial umum yang sudah diakui. Diantara pembelajaran valuasi, Grand Metropolitan memiliki cara untuk melakukan valuasi brand dengan menentukan perbedaan antara harga akuisisi dan aset tetap. Sedangkan Interbrand menggunakan perkalian subjektif profit brand berbasis performa brand yang dibagi menjadi tujuh dimensi : 


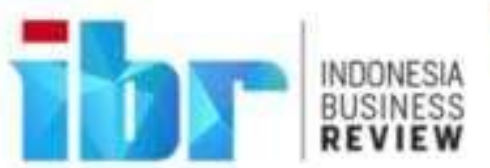

Vol. 3. No. 2, 2020

Kepemimpinan, Stabilitas, Stabilitas Pasar, Internasional, Tren Pendukung, dan Perlindungan (Keller 1993).

Konstruk dari ekuitas merek berbasis pelanggan diambil konsep konstruk yang diusung oleh management gurus. Yang dimana Aaker (1991) fokus kepada lima dimensi yaitu Kesadaran merek, Asosiasi Merek, Loyalitas Persepsi Kualitas, Loyalitas Merek, dan Aset Merek lainnya. Sedangkan Keller (1993) menggunakan dua pendekatan yaitu langsung dan tak langsung untuk mengukur ekuitas merek berbasis pelanggan, yaitu kesadaran merek dan citra merek. Pendekatan tidak langsung digunakan untuk mengidentifikasi sumber potensial dari ekuitas merek berbasis pelanggan seperti saluran distribusi dan keefektifan komunikasi pemasaran, dan kesuksesan brand external dengan mengukur kesadaran merek dan karakteristik hubungan dengan asosiasi merek. Sedangkan pendekatan langsung fokus terhadap respon konsumen terhadap berbagai program marketing elemen perusahaan (Keller 2003).

Silverman et al., (1999) mengeksplorasi pengukuran hubungan antara customer based dan finansial/market-based brand equity. Dampak keseluruhan dari penelitian customer-based brand menganggap pengukuran menggunakan sudut pandang customer-based merupakan refleksi yang akurat dari performa brand di pasar. Oleh karena itu pengukuran ini dapat digunakan juga sebagai pemicu peningkatan profit dan pendapatan finansial untuk perusahaan (Lassar et al, 1995).

\section{Hipotesa}

Studi ini bertujuan untuk melihat hubungan sebab akibat dari empat dimensi ekuitas merek. Beberapa penelitian telah dilakukan untuk menyelidiki secara empiris bagaimana dimensi ekuitas merek saling berhubungan. Dengan demikian, sebagian besar studi dilakukan untuk melihat atau membuktikan hubungan asosiatif antara dimensi ekuitas merek (Yoo et al., 2000; Pappu et al., 2005). Hubungan merek dengan asosiasi yang berbeda merupakan kesadaran merek dalam memori (Keller 2003). Sehingga, konsumen pertama-tama harus menyadari suatu merek untuk kemudian memiliki seperangkat asosiasi merek (Aaker 1991). Kesadaran merek mempengaruhi pembentukan dan kekuatan asosiasi merek, termasuk kualitas yang dirasakan (Keller 1993; Pitta \& Katsanis 1995; Keller \& Lehmann 2003). Oleh karena itu, dimensi ekuitas merek dapat dikatakan merupakan anteseden penting bagi asosiasi merek dan persepsi kualitas. Berdasarkan penjelasan diatas tentang pentingnya hubungan asosiatif antara dimensi merek 


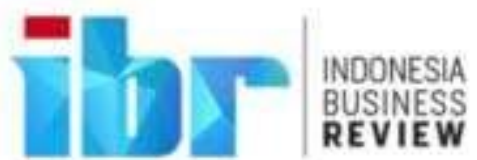

Vol. 3. No. 2, 2020

untuk pembentukan kekuatan ekuitas merek. Penulis membuat hipotesis yang terkait dan telah diuji secara terpisah di bagian selanjutnya dari penelitian ini.

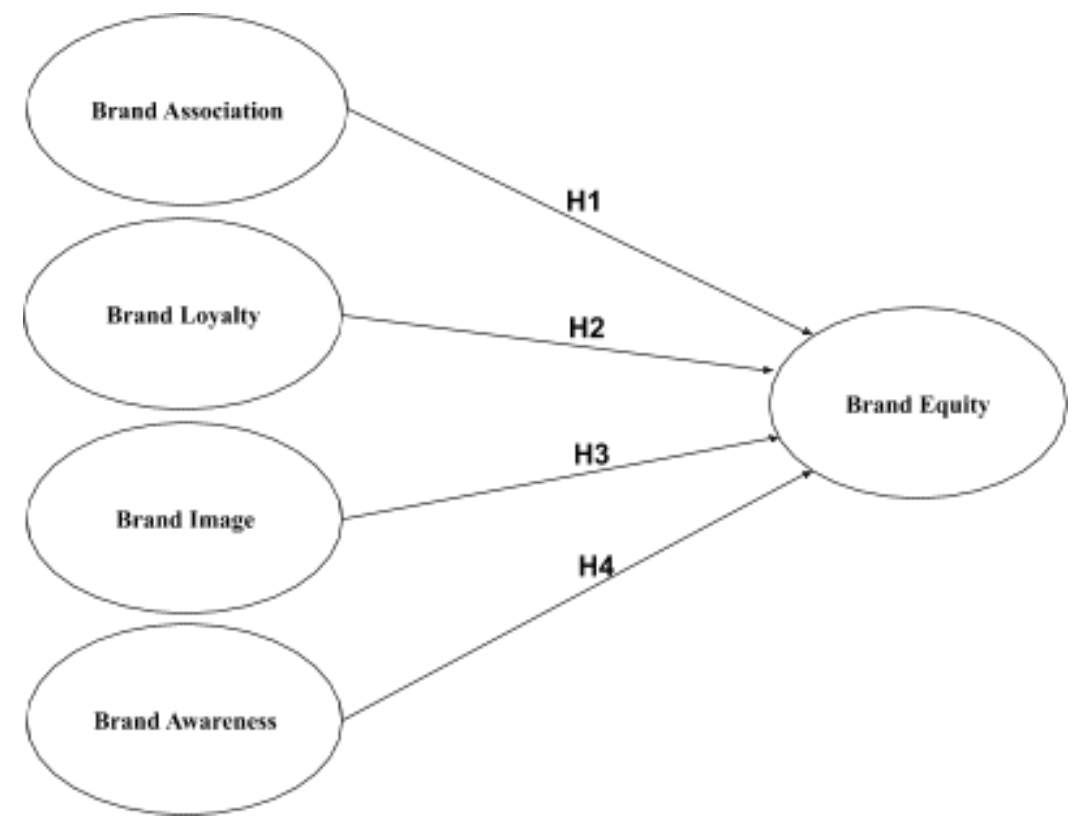

Gambar 1. Framework Penelitian

\section{- Brand Association}

Aaker (1991) mengartikan Asosiasi merek merupakan hal-hal yang berkaitan di dalam memori sebuah merek. Pentingnya asosiasi nama merek ditekankan oleh Rio et al. (2001a) dalam memperoleh keunggulan diferensial. Asosiasi organisasi dan produk dianggap sebagai kategori yang paling banyak dirujuk menurut tipologi asosiasi merek (Chen 2001). Asosiasi dapat mewakili keputusan pembelian untuk loyalitas merek dan penciptaan nilai bagi pelanggan dan perusahaan. Rio et al. (2001b) mengatakan asosiasi merek merupakan salah satu kunci pembentukan dan manajemen ekuitas dari merek. Dalam hal ini, ekuitas merek dengan nilai tinggi menyiratkan jika pelanggan memiliki asosiasi yang signifikan sehubungan dengan merek. Dengan demikian, hipotesis pertama adalah :

\section{H1. Asosiasi merek memiliki dampak langsung terhadap ekuitas merek.}

\section{- $\quad$ Brand Loyalty}

Loyalitas terhadap merek dapat dibagi menurut perspektif perilaku, sikap, dan pilihan. Perspektif perilaku memiliki pertimbangan dalam jumlah pembelian merek tertentu, sementara 


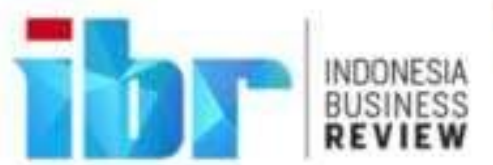

Vol. 3. No. 2, 2020

perspektif sikap menggabungkan sisi preferensi dan disposisi konsumen terhadap merek tertentu. Serta perspektif pilihan fokus terhadap faktor atau alasan pembelian sehingga dapat mempengaruhi pilihan kepada merek tertentu (Javalgi \& Moberg, 1997). Ahmed (2011), Huang \& Huddleston (2009), Lam (2007) dan Martenson (2007) mengatakan loyalitas merek merupakan faktor yang mempengaruhi keputusan pembelian mereka ke produk yang sama. Konsumen yang membeli kembali atau mem-repatronisasi produk pilihan secara konsisten telah memulai pembelian berulang merek yang sama merupakan salah satu bentuk loyalitas merek (Luarn \& Lin 2003). Konsumen mengembangkan loyalitas merek dengan menciptakan output positif dari ekuitas merek yang secara positif menimbulkan preferensi merek dibandingkan merek lain (Atilgan et al., 2005; Binninger 2008; Ling 2013; Vogel et al., 2008; Zhang et al., 2014). Sehingga, hipotesis kedua adalah:

\section{H2. Loyalitas merek memiliki dampak langsung terhadap ekuitas merek.}

- Brand Image

Penilaian citra merek terkait dengan penggunaan merek oleh konsumen mencerminkan makna simbolis dari konsumsi dan identitas mereka dalam mengekspresikan diri (Lau \& Phau 2007). Lau dan Phau (2007) juga menyatakan bahwa konsumen secara teratur mengaitkan merek dengan selebriti atau tokoh sejarah terkenal. Keller (1993) mengatakan ada dua pendekatan dasar (langsung dan tidak langsung) untuk mengukur ekuitas merek berbasis pelanggan yang menekankan dua konstruksi yaitu kesadaran merek dan citra merek. Ketika seorang konsumen terbiasa dengan suatu merek, ia memiliki citra yang kuat, unik dan baik di benaknya (Keller 1993). Pengetahuan ini mencerminkan kesadaran merek atau gambar yang terkait dengan merek (Aaker 1991; Keller 1993). Penelitian tentang advokasi ekuitas merek bahwa dimensi ekuitas merek, seperti citra merek, dapat diperluas untuk memperjelas struktur konstruk ini secara rinci (Yoo \& Donthu 2001). Berdasarkan penjabaran diatas hipotesis ketiga, yaitu:

\section{H3. Gambaran merek memiliki dampak langsung terhadap ekuitas merek.}

\section{- Brand Awareness}

Ekuitas dari merek dalam hal kesadaran merek merupakan suatu keunikan asosiasi merek yang dimiliki konsumen dalam ingatan (Keller 1993). Selain itu, Aaker (1996) memandang bahwa kesadaran merek merupakan langkah pertama dalam menghasilkan ekuitas merek. Dimensi ini merujuk kepada apakah konsumen bisa menarik kembali atau mengidentifikasi suatu 
merek dan berkaitan dengan kekuatan kehadiran merek di dalam benak konsumen. Kesadaran merek berdampak secara signifikan terhadap pengambilan keputusan konsumen dimana secara umum konsumen menggunakannya sebagai keputusan heuristik yang memberikan keuntungan bagi manajemen ekuitas merek berbasis pelanggan (Chung et al., 2013; Huang \& Sarigollu 2011; Norazah 2013a). Menurut Keller (2003), brand equity berbasis pelanggan terjadi saat konsumen mempunyai tingkat kesadaran dan kelaziman yang tinggi terhadap merek tersebut dan memiliki berbagai kumpulan merek yang kuat, bermanfaat, dan khas dalam ingatan.

\section{H4. Kesadaran merek memiliki dampak langsung terhadap ekuitas merek.}

\section{- Metodologi Penelitian}

Kerangka pada gambar dibawah diuji untuk mengetahui hubungan hipotesis di dalam menilai Brand Equity Perusahaan. Penelitian dilakukan dengan cara mengumpulkan data melalui survey online yang dilakukan dengan memilih beberapa lokasi kota yaitu Jakarta, Bogor, Depok, Tangerang, Bekasi. Hal ini dikarenakan banyaknya pengguna brand agen perjalanan daring (OTA) di daerah tersebut. Data hasil dari penelitian dikelola sendiri menggunakan aplikasi SPSS oleh penulis. Dari hasil penyebaran kuesioner melalui survey online didapatkan responden sebanyak 329 orang, dimana jumlah tersebut jauh di atas sampel kritis yaitu 200 responden untuk mengembangkan model persamaan struktural (Hair et al., 1998). Sampel penelitian diseleksi terlebih dahulu untuk mendapatkan responden yang pernah melihat iklan perusahaan melalui media sosial. Partisipasi responden murni dilakukan dengan sukarela.

Kuesioner terstruktur dibagi menjadi tiga bagian. Bagian 1 terdiri dari identitas, usia, jenis kelamin, domisili, pekerjaan, dan pengeluaran perbulan responden. Bagian 2 untuk mengetahui pengalaman responden menggunakan online travel agent dan pengalaman menggunakan perusahaan online travel agent yang menjadi objek penelitian. Bagian 3 meneliti tentang faktor-faktor yang mempengaruhi nilai ekuitas dari perusahaan yang merupakan variabel dependen, dengan cara menilai pengaruh dari beberapa faktor (variabel independen) berikut yaitu : brand association, brand loyalty, brand image, dan brand awareness. Dalam menilai pengaruh nilai ekuitas dari perusahaan digunakan metode pengukuran skala Likert lima poin mulai dari nilai 1 (sangat tidak setuju) hingga nilai 5 (sangat setuju). Data yang didapatkan dari hasil kuesioner dianalisis menggunakan analisis reliabilitas dan analisis regresi berganda. 


\section{Analisis Data}

\section{- Analisa Deskriptif}

Total responden penelitian yang diraih sebesar 329 responden, 50,76\% laki-laki dan 49,24\% perempuan. Mayoritas responden berumur 19-24 atau sebesar $51,37 \%$ dari total responden yang diperoleh. Kemudian disusul responden berumur 25-35 dengan sebesar 38,91\%. Sebagian besar responden penelitian merupakan responden domisili Jakarta Selatan (27,05\%), sedangkan responden domisili Jakarta Utara hanya sebesar 3,34\%. Adapun pekerjaan responden, pekerjaan karyawan mendapati posisi terbanyak dalam responden penelitian ini dengan nilai sebesar 48,33\%. Total responden yang didapatkan sudah melalui tahapan screening perihal responden pernah melihat iklan agen perjalanan daring di media sosial. Tabel 4.1 memberikan hasil lengkap mengenai analisis deskriptif dari penelitian ini.

Tabel 4.1. Profil Demografis Responden

\begin{tabular}{|l|r|r|}
\hline \multicolumn{2}{|l|}{ Frequency } & Percent (\%) \\
\hline Gender & 167 & $50.76 \%$ \\
\hline Male & 162 & $49.24 \%$ \\
\hline Female & 329 & $100.00 \%$ \\
\hline Age & & \\
\hline$<18$ & 5 & $1.52 \%$ \\
\hline $19-24$ & 169 & $51.37 \%$ \\
\hline $25-35$ & 128 & $38.91 \%$ \\
\hline$>36$ & 27 & $8.21 \%$ \\
\hline Total & 329 & $100.00 \%$ \\
\hline Residence & & $27.05 \%$ \\
\hline Jakarta Timur & 53 & $16.11 \%$ \\
\hline Jakarta Barat & 30 & $9.12 \%$ \\
\hline Jakarta Utara & 11 & $3.34 \%$ \\
\hline Jakarta Pusat & 19 & $5.78 \%$ \\
\hline Jakarta Selatan & & \\
\hline
\end{tabular}


Vol. 3. No. 2, 2020

\begin{tabular}{|l|r|r|}
\hline Pulau Seribu & 0 & $0.00 \%$ \\
\hline Depok & 22 & $6.69 \%$ \\
\hline Bogor & 21 & $6.38 \%$ \\
\hline Tangerang & 63 & $19.15 \%$ \\
\hline Bekasi & 21 & $6.38 \%$ \\
\hline Total & 329 & $100.00 \%$ \\
\hline Occupation & & $37.08 \%$ \\
\hline Mahasiswa & 122 & $0.30 \%$ \\
\hline Pelajar & 1 & $48.33 \%$ \\
\hline Karyawan & 159 & $11.25 \%$ \\
\hline Wiraswasta & 37 & $3.04 \%$ \\
\hline Pegawai Negeri Sipil (PNS) & 10 & $100.00 \%$ \\
\hline Total & 329 & \\
\hline Sumber Olahan Tim Pens & & \\
\hline
\end{tabular}

Sumber: Olahan Tim Peneliti (2019)

Tabel 4.2 dibawah menampilkan pengalaman responden menggunakan agen perjalanan daring . Mayoritas responden sebesar 33,43\% dari total responden telah menghabiskan rentang Rp 3.000.000,00 - Rp 5.000.000,00 untuk pembelian tiket melalui agen perjalanan daring dalam setahun. Mengenai hal frekuensi pembelian tiket travel melalui agen perjalanan daring, $60 \%$ responden telah melakukan pembelian tiket travel dua hingga tiga kali dalam setahun dan mayoritas responden menyukai agen perjalanan online (OTA) Traveloka daripada Tiket.com, pegi - pegi, dan trivago.

Tabel 4.2. Pengalaman Konsumen Menggunakan Agen Perjalanan Online (OTA)

\begin{tabular}{|l|r|r|}
\hline & Frequency & Percent (\%) \\
\hline $\begin{array}{l}\text { Money spent for buying ticket in Online Travel Agency (OTA) in } \\
\text { one year }\end{array}$ & & \\
\hline$<$ Rp 1.500 .000 & 32 & $9.73 \%$ \\
\hline Rp $1.500 .000-\operatorname{Rp~} 3.000 .000$ & 93 & $28.27 \%$ \\
\hline
\end{tabular}


Vol. 3. No. 2, 2020

Rp 3.000.000 - Rp 5.000.000

10

$33.43 \%$

$>\operatorname{Rp} 5.000 .000$

94

$28.57 \%$

Total

329

$100.00 \%$

Frequency of buying ticket in Online Travel Agency (OTA) in one year

2 - 3 kali

201

$61.09 \%$

4 - 7 kali

78

$23.71 \%$

$>8$ kali

50

$15.20 \%$

Total

329

$100.00 \%$

Type of favourite Online Travel Agency (OTA)

Traveloka

Tiket.com

Pegi - Pegi

Trivago

Total

329

276

$83.89 \%$

41

$12.46 \%$

11

$3.34 \%$

1

$0.30 \%$

Total

(3)

$100.00 \%$

Sumber: Olahan Tim Peneliti (2019)

Selanjutnya Tabel 4.3 dibawah menjelaskan mengenai analisis deskriptif yang telah dilakukan oleh tim peneliti terhadap tiap konstruk melalui aplikasi SPSS. Berdasarkan aplikasi tersebut, nilai mean yang dihasilkan dari tiap konstruk lebih besar daripada 3.5 dari nilai maksimum 5. Sebagai contoh nilai mean dari konstruk citra merek (brand image) adalah $3.9>$ 3.5 dengan demikian nilai tersebut memiliki nilai distribusi cenderung kearah nilai maksimum.

Sehingga responden setuju/sepakat terhadap citra merek (brand image) .

Tabel 4.3 Statistik Deskriptif Konstruk Penelitian

\begin{tabular}{|c|c|c|c|c|c|}
\hline Construct & Number & Minimum & Maximum & Mean & Std. Deviation \\
\hline Brand Association & 329 & 2.00 & 5.00 & 3.8146 & 0.57129 \\
\hline
\end{tabular}


Vol. 3. No. 2, 2020

\begin{tabular}{|c|c|c|c|c|c|}
\hline Brand Loyalty & 329 & 2.00 & 5.00 & 3.5690 & 0.64535 \\
\hline Brand Image & 329 & 2.00 & 5.00 & 3.9463 & 0.56563 \\
\hline Brand Awareness & 329 & 2.00 & 5.00 & 4.0766 & 0.54969 \\
\hline Brand Equity & 329 & 2.00 & 5.00 & 3.9195 & 0.63225 \\
\hline
\end{tabular}

Sumber: Olahan Tim Peneliti (2019)

\section{- Uji Validitas dan Reliabilitas Data}

Pengujian validitas konstruk menggunakan analisis komponen utama dengan rotasi varimax. Pemilihan analisa rotasi varimax dipilih sebagai metode ekstraksi untuk menguji validitas konstruk pada 20 pertanyaan. The Kaiser-Meyer-Olkin (KMO) merupakan suatu ukuran kecukupan sampel yang digunakan dalam mengkonfirmasi keselarasan proses dengan analisis dalam hal mengurangi jumlah item, dan mengidentifikasi dimensi variabel lain yang tidak disebutkan dalam penelitian.

Pertanyaan (item) apa pun yang gagal dimuat pada faktor tunggal 0,50 atau kurang akan dibatalkan. Proses analisis faktor dengan menjatuhkan item diulangi sampai semua item dimuat pada 0,50 atau lebih besar pada satu dan hanya satu faktor. Perhitungan menggunakan komputasi dengan aplikasi SPSS. Selain analisa KMO untuk pengujian reliabilitas tiap konstruk, penelitian ini menambahkan koefisien signifikansi Barlett, dan koefisien Eigenvalue sebagai tambahan bukti tes validitas untuk tiap konstruk. Kemudian untuk analisis reliabilitas tiap konstruk digunakan dengan mengukur konsistensi internal melalui Cronbach $\alpha$. Semua konstruk dapat diandalkan jika tiap konstruk memiliki nilai $\alpha$ Cronbach melebihi kriteria 0,700 (Hair et al., 2010).

Tabel 4.4 menunjukan informasi mengenai analisis faktor KMO, signifikansi Barlett, dan koefisien Eigenvalue sebagai alat untuk tes validitas dan Cronbach $\alpha$ sebagai alat untuk tes reliabilitas tiap konstruk yang diuji.

Table 4.4. Analisis Reliabilitas dan Validitas Tiap Konstruk 
Vol. 3. No. 2, 2020

\begin{tabular}{|c|c|c|c|c|c|c|}
\hline Construct & Item & Loadings & KMO & $\begin{array}{c}\text { Barlett's } \\
\text { (Sign.) }\end{array}$ & Eigenvalues & $\begin{array}{c}\text { Cronbach's } \\
\text { Alpha }\end{array}$ \\
\hline $\begin{array}{l}\text { Brand } \\
\text { Association }\end{array}$ & $\begin{array}{l}\text { BAS_1 } \\
\text { BAS_2 } \\
\text { BAS_3 }\end{array}$ & $\begin{array}{l}0.741 \\
0.720 \\
0.788\end{array}$ & 0.801 & 0.000 & 2.731 & 0.790 \\
\hline & $\begin{array}{l}\text { BAS_4 } \\
\text { BAS_5 }\end{array}$ & $\begin{array}{l}0.753 \\
0.690\end{array}$ & & & & \\
\hline Brand Loyalty & $\begin{array}{l}\text { BLOY_1 } \\
\text { BLOY_2 } \\
\text { BLOY_3 } \\
\text { BLOY_4 } \\
\text { BLOY_5 }\end{array}$ & $\begin{array}{l}0.640 \\
0.762 \\
0.729 \\
0.671 \\
0.797\end{array}$ & 0,763 & 0.000 & 2.606 & 0.763 \\
\hline Brand Image & $\begin{array}{l}\text { BIM_1 } \\
\text { BIM_2 } \\
\text { BIM_3 }\end{array}$ & $\begin{array}{l}0.756 \\
0.887 \\
0.832\end{array}$ & 0.646 & 0.000 & 2.051 & 0.759 \\
\hline $\begin{array}{l}\text { Brand } \\
\text { Awareness }\end{array}$ & $\begin{array}{l}\text { BAW_1 } \\
\text { BAW_2 } \\
\text { BAW_3 } \\
\text { BAW_4 } \\
\text { BAW_5 }\end{array}$ & $\begin{array}{l}0.726 \\
0.771 \\
0.880 \\
0.812 \\
0.808\end{array}$ & 0,852 & 0.000 & 3.210 & 0.857 \\
\hline Brand Equity & $\begin{array}{l}\text { BEq_1 } \\
\text { BEq_2 }\end{array}$ & $\begin{array}{l}0.844 \\
0.844\end{array}$ & 0,500 & 0.000 & 1.423 & 0.583 \\
\hline
\end{tabular}

Sumber: Olahan Tim Peneliti (2019)

Tabel 4.4 menjelaskan bahwa tiap konstruk yang telah dilakukan analisa mendapatkan nilai koefisien Kaiser - Meyer - Olkin (KMO) > 0,5. Maka dari itu data yang didapatkan untuk penelitian menunjukan hasil validasi dengan baik. Disamping itu, nilai Eigenvalues yang 
dihasilkan dari beberapa konstruk memiliki nilai diatas 1, sehingga konstruk yang diperoleh dari pertanyaan yang dihimpun telah masuk kedalam konstruk yang sesuai. Kemudian dengan menggunakan analisis Barlett's menghasilkan nilai yang signifikan dari tiap konstruk.

Kemudian untuk hasil uji reliabilitas dengan analisis Cronbach Alpha, dihasilkan dengan nilai lebih besar dari 0,7 dari tiap konstruk. Namun konstruk brand equity memiliki nilai dibawah 0,7. Maka konstruk brand equity tidak bebas dari kesalahan acak.

\section{- Analisis Regresi Linear Berganda}

Analisis ini dilakukan dengan menggunakan ekuitas merek dimasukkan sebagai variabel dependen, dan loyalitas merek, kesadaran merek, asosiasi merek, dan gambaran merek dimasukan sebagai variabel independen. Hasil ini ditampilkan pada tabel 4.5 dibawah dengan hasil nilai adjusted $\mathrm{R}^{2}$ sebesar 0,441 , dengan demikian hal ini menunjukan variabel independen menghasilkan $44 \%$ dari variance variabel dependen. Sehingga variabel independen yang digunakan dapat menjelaskan $44 \%$ dari variabel dependen. Maka dari itu, penelitian kali ini menghasilkan 56\% variabel independen lainya yang tidak dipertimbangkan.

Tabel 4.5 menerangkan beberapa variabel independen yang dapat berdampak terhadap variabel dependen (brand equity). Konstruk brand association menunjukkan bahwa hasilnya tidak signifikan $(\beta=-0.046)$, sehingga variabel dependen tersebut tidak berpengaruh terhadap perubahan variabel dependen. Sedangkan variabel independen lainya seperti brand loyalty $(\beta=$ $0.456)$, brand image $(\beta=0.171)$, brand awareness $(\beta=0.219)$ menunjukkan hasil yang signifikan terhadap perubahan brand equity dikarenakan nilai $\beta$ positif dan nilai Sig dari empat variabel independen tersebut $<0.005$.

Tabel 4.5. Hasil Penelitian Analisis Regresi Linear Berganda Evaluasi Brand Agen Perjalanan Daring Melalui Media Sosial

\begin{tabular}{|c|c|c|c|c|c|c|c|}
\hline Model & $\begin{array}{c}\text { Standardized } \\
\text { regression } \\
\text { coefficients (Beta) }\end{array}$ & $\begin{array}{c}\text { Tolerance } \\
\text { Value }\end{array}$ & $\mathbf{t}$ & Sig. & $F$ & $R^{2}$ & Adjusted $R^{2}$ \\
\hline (Constant) & 0.897 & & 4.074 & 0.000 & 63.841 & 0.441 & 0.434 \\
\hline Brand Association & -0.046 & & -0.735 & 0.463 & & & \\
\hline
\end{tabular}




\begin{tabular}{|l|l|l|l|l|l|l|l|}
\hline Brand Loyalty & 0.456 & & 8.580 & 0.000 & & & \\
\hline Brand Image & 0.171 & & 2.659 & 0.008 & & & \\
\hline Brand Awareness & 0.219 & & 3.355 & 0.001 & & & \\
\hline Notes: Dependent variable: Brand Equity & & & & & & \\
\hline
\end{tabular}

Sumber: Olahan Tim Peneliti (2019)

Berdasarkan dari beberapa analisis diatas dapat diambil beberapa kesimpulan mengenai keterkaitan asosiasi merek, loyalitas merek, citra merek, dan kesadaran merek terhadap ekuitas merek dari agen perjalanan daring di kalangan konsumen daerah JABODETABEK. Hasil empiris melalui analisis regresi berganda menegaskan bahwa keterkaitan loyalitas merek, kesadaran merek, dan citra merek dengan ekuitas merek berdampak positif dari agen perjalanan daring. Lebih lanjut lagi, hasil penelitian menunjukan bahwa terdapat korelasi antara loyalitas merek dengan ekuitas merek sesuai dengan analisa Hipotesa dalam $\mathrm{H} 2$ adalah positif dan signifikan sehingga mendukung hasil penelitian (Luarn dan Lin, 2003).

Investigasi lebih lanjut ditemukan bahwa ekuitas merek juga dipengaruhi oleh kesadaran merek (H4) dalam pengertian bahwa keputusan pelanggan untuk membeli tiket travel tergantung pada kesadaran pelanggan terhadap merek dari agen perjalanan daring di media sosial. Pelanggan dengan terang dapat mengakui merek agen perjalanan daring tertentu daripada merek lain melalui bagaimana tampilan dan karakteristik dari merek tersebut di jejaring sosial. Sehingga penelitian yang sudah dilakukan konsisten terhadap penelitian sebelumnya yaitu Chung et al., (2013), Huang dan Sarigollu, (2011), Norazah, (2013a).

Selain itu, citra merek (H3) ditemukan dapat mempengaruhi ekuitas merek secara signifikan dan positif sehingga hasil penelitian ini mendukung hasil penelitian (Lau dan Phau, 2007). Hasil mengkonfirmasi bahwa dalam menilai citra agen perjalanan daring dengan pelanggan melalui media sosial dapat memunculkan makna secara simbolis dari konsumen dan identitas mereka dalam hal mengekspresikan diri.

Sedangkan konstruk asosiasi merek tidak signifikan dan berdampak negatif terhadap perubahan dari ekuitas merek agen perjalanan daring. Sehingga hasil penelitian Rio et al. (2001b) 
tidak relevan dengan penelitian ini. Hal ini dikarenakan terdapat perbedaan budaya dan kebiasaan dari responden yang didapatkan oleh tim peneliti. Pengisi survei yang dijaring oleh tim peneliti merupakan pengisi survei yang bertempat tinggal di daerah JABODETABEK sehingga hal tersebut yang dapat menjadi penyebab kenapa konstruk asosiasi merek tidak signifikan mempengaruhi ekuitas merek.

\section{Kesimpulan}

Hasil dari penelitian menunjukan beberapa faktor yang mempengaruhi penggunaan media sosial terhadap ekuitas merek agen perjalanan melalui daring. Hasil penelitian diharapkan dapat memberikan petunjuk kepada pemasar dan praktisi untuk merumuskan strategi. Dengan adanya perumusan strategi yang efektif diharapkan perusahaan dapat meningkatkan ekuitas merek yang nantinya berdampak pada keunggulan kompetitif. Hasil dari perhitungan regresi berganda menyimpulkan bahwa tidak semua hipotesis mempunyai pengaruh langsung terhadap ekuitas merek. Hasil tersebut menunjukan bahwa loyalitas merek mempunyai pengaruh yang paling kuat terhadap ekuitas merek dengan pengaruh penggunaan media sosial agen perjalanan melalui daring, selanjutnya diikuti oleh kesadaran dan citra merek secara berturut-turut. Sedangkan asosiasi merek menunjukan hasil negatif atau tidak berpengaruh langsung terhadap ekuitas merek.

Menurut Aaker (1991) Pada ekuitas merek terdapat fokus lima dimensi yang merupakan : kesadaran merek, asosiasi merek, loyalitas merek, kualitas merek, serta aset merek eksklusif. Sedangkan pendapat dari Keller (1993) dalam hal mengukur ekuitas merek dapat dikerjakan dengan mengadopsi dua pendekatan dasar (langsung dan tidak langsung). Pendekatan langsung yang berbasis kepada pelanggan menekankan dua konstruk yaitu kesadaran merek dan citra merek. Sedangkan pendekatan tidak langsung dilakukan dengan mengidentifikasi sumber potensial saluran distribusi ekuitas merek berbasis pelanggan, efektivitas komunikasi pemasaran, dan keberhasilan perluasan merek dengan mengukur kesadaran merek dan karakteristik serta hubungan di antara asosiasi merek. Oleh karena itu berdasarkan pernyataan dari Keller tersebut untuk mengukur kesadaran merek dan karakteristik serta hubungan di antara asosiasi merek terhadap ekuitas merek memiliki pengaruh tidak langsung, sehingga tidak dapat menggambarkan secara langsung hubungan antara asosiasi merek pada ekuitas merek. 
Namun studi penelitian ini memiliki beberapa keterbatasan, yaitu : Pertama, penelitian dilakukan oleh mahasiswa penuh waktu yang sedang menempuh pendidikan di Universitas Prasetiya Mulya Jakarta dengan keterbatasan waktu untuk melakukan penelitian. Sehingga hasil yang didapatkan dimungkinkan tidak dapat menggambarkan secara generalisasi seluruh penduduk JABODETABEK yang menggunakan media sosial dan menjadi target pemasaran agen perjalanan daring. Kedua, berdasarkan pernyataan Keller diatas penelitian kedepan sebaiknya mempertimbangkan aspek pendekatan tidak langsung yang berdampak pada pengukuran asosiasi merek, dikarenakan dari hasil penelitian kami tidak terdapat kaitan antara asosiasi merek pada ekuitas merek. Penyebab tidak validnya hipotesa kami mungkin juga dikarenakan pemutaran iklan di media youtube dapat dilewati dalam waktu 5 detik sehingga tidak efektif bagi target perusahaan agen perjalanan daring. Selain itu behaviour dari pengguna media sosial di JABODETABEK yang cukup kompleks menjadi hal yang harus dipertimbangkan oleh peneliti selanjutnya. 


\section{Daftar Pustaka}

Aaker, D.A. (1991), Managing Brand Equity. Capitalizing on the Value of Brand Name, The Free Press, New York, NY.

Ahmed, H.T. (2011), "The impact of distribution intensity on brand preference and brand loyalty", International Journal of Marketing Studies, Vol. 3 No. 3, pp. 56-66.

Atilgan, E., Aksoy, S. and Akinci, S. (2005), "Determinants of the brand equity: a verification approach in the beverage industry in Turkey", Marketing Intelligence \& Planning, Vol. 23 No. 3, pp. 237-248.

Binninger, A.S. (2008), "Exploring the relationships between retail brands and consumer store loyalty", International Journal of Retail \& Distribution Management, Vol. 36 No. 2, pp. 94-110.

Buil I., Martinez E. and Leslie de Chernatony (2013), "The influence of brand equity on consumer responses", Journal of Consumer Marketing, Emerald Group Publishing Limited 30, No.1, (January): 62-74.

Chung, Y.J., Lee, J. and Heath, L.R. (2013), "Public relations aspects of brand attitudes and customer activity”, Public Relations Review, Vol. 39 No. 5, pp. 432-439.

Cobb-Walgren, C.J. and Ruble, C.A. (1995), "Brand equity, brand preference, and purchase intent”, Journal of Advertising, Vol. 24 No. 3, pp. 25-41.

Feldwick, P. (1996), “Do we really need brand equity?”, The Journal of Brand Management, Vol. 4 No. 1, pp. 9-28.

Huang, Y. and Huddleston, P. (2009), "Retailer premium own-brands: creating customer loyalty through own-brand products advantage", International Journal of Retail \& Distribution Management, Vol. 37 No. 11, pp. 975-992.

Huang, R. and Sarigollu, E. (2011), "How brand awareness relates to market outcome, brand equity, and the marketing mix", Journal of Business Research, Vol. 65 No. 1, pp. 92-99. 
Javalgi, R.R. and Moberg, C.R. (1997), "Service loyalty: implications for service providers", Journal of Services Marketing, Vol. 11 No. 3, pp. 165-79.

Keller, K.L. (1993), “Conceptualizing, measuring, and managing customer-based brand equity”, Journal of Marketing, Vol. 57 No. 1, pp. 1-22.

Keller, K.L. (2003), Strategic Brand Management: Building, Measuring and Managing Brand Equity, 2nd ed., Prentice-Hall, Englewood Cliffs, NJ.

Keller, K.L. (2003), Strategic Brand Management: Building, Measuring, and Managing Brand Equity, 2nd ed., Prentice Hall, New York, NY.

Keller, K.L. (2003), Strategic Brand Management: Building, Measuring and Managing Brand Equity, 2nd ed., Prentice-Hall, Englewood Cliffs, NJ.

Keller, K.L. and Lehmann, D.R. (2003), “How do brands create value?", Marketing Management, May/June, pp. 27-31.

Lam, D. (2007), “Cultural influence on proneness to brand loyalty”, Journal of International Consumer Marketing, Vol. 19 No. 3, pp. 7-21.

Lau, K.C. and Phau, I. (2007), "Extending symbolic brands using their personality: examining antecedents and implications towards brand image fit and brand dilution", Psychology and Marketing, Vol. 24 No. 5, pp. 421-444.

Ling, E.S. (2013), "The mediating effects of brand association, brand loyalty, brand image and perceived quality on brand equity”, Asian Social Science, Vol. 9 No. 3, pp. 125-134.

Luarn, P. and Lin, H.H. (2003), "A customer loyalty model for e-service context", Journal of Electronic Commerce Research, Vol. 4 No. 4, pp. 157-167.

Lassar, W., Mittal, B. and Sharma, A. (1995), "Measuring customer-based brand equity”, Journal of Consumer Marketing, Vol. 12 No. 4, pp. 11-19. 
Martenson, R. (2007), “Corporate brand image, satisfaction and store loyalty: a study of the store as a brand, store brands and manufacturer brands", International Journal of Retail \& Distribution Management, Vol. 35 No. 7, pp. 544-555.

Motameni, R. and Shahrokhi, M. (1998), "Brand equity valuation: a global perspective”, Journal of Product \& Brand Management, Vol. 7 No. 4, pp. 275-91.

Norazah, M.S. (2013a), “Green awareness effects on consumer's purchasing decision: some insights from Malaysia”, International Journal of Asia Pacific Studies, Vol. 9 No. 2, pp. 49-63.

Pitta, D.A. and Katsanis, L.P. (1995), "Understanding brand equity for successful brand extension", Journal of Consumer Marketing, Vol. 12 No. 4, pp. 51-64.

Pappu, R., Quester, P.G. and Cooksey, R.W. (2005), “Consumer-based brand equity: improving the measurement. Empirical evidence”, Journal of Product and Brand Management, Vol. 14 No. 3, pp. 143-54.

Rio, A., Vazquez, R. and Iglesias, V. (2001a), "The role of the brand name in obtaining differential advantages", Journal of Product \& Brand Management, Vol. 10 No. 7, pp. 452-65.

Rio, A., Vazquez, R. and Iglesias, V. (2001b), "The effects of brand associations on consumer response”, Journal of Consumer Marketing, Vol. 18 No. 5, pp. 410-25.

Rio, A., Vazquez, R. and Iglesias, V. (2001a), "The role of the brand name in obtaining differential advantages", Journal of Product \& Brand Management, Vol. 10 No. 7, pp. 452-65.

Sasmita J. dan MS. Norazah (2015), "Young consumers' insights on brand equity: Effects of brand association, brand loyalty, brand awareness, and brand image", International Journal of Retail \& Distribution Management, Emerald Group Publishing Limited 43, No.3, (FebruarySeptember): 276-292.

Simon, C.J. and Sullivan, M.W. (1993), "The measurement and determinants of brand equity:a financial approach”, Marketing Science, Vol. 12 No. 1, pp. 28-53. 
Silverman, S.N., Sprott, D.E. and Pascal, M.J. (1999), "Relating consumer-based sources of brand equity to market outcomes", Advances in Consumer Research, Vol. 26 No. 1, pp. 352-8.

Vogel, V., Evanschitzky, H. and Ramaseshan, B. (2008), "Customer equity drivers and future sales", Journal of Marketing, Vol. 72 No. 6, pp. 98-108.

Wood, L. (2000), "Brands and brand equity: definition and management", Management Decision, Vol. 38 No. 9, pp. 662-9.

Yoo, B., Donthu, N. and Lee, S. (2000), “An examination of selected marketing mix elements and brand equity", Journal of the Academy of Marketing Science, Vol. 28 No. 2, pp. 195-211.

Zhang, S.S., van Doorn, J. and Leeflang, P.S.H. (2014), "Does the importance of value, brand and relationship equity for customer loyalty differ between Eastern and Western cultures?", International Business Review, Vol. 23 No. 2014, pp. 284-292. 